\title{
Rural as Periphery Per Se? Unravelling the Disc ursive Node
}

\author{
Bianka Plüschke-Altof
}

\begin{abstract}
Despite often being used interchangeably, the dominant equation of the rural with the peripheral is not self-evident. In order to critically scrutinize the discursive node, the aim of this article is twofold. On one hand, it argues for overcoming the prevalent urban-rural divide and dominant structural approaches in sociological and geographical research by introducing discursive peripheralization as a conceptual framework, which allows the analysis of the discursive (re-)production of socio-spatial inequalities on and between different scales. On the other hand, this article explores how rural areas are constituted as peripheries within a hegemonic discourse naturalizing the ascription of development (non-)potentials. Following a critical discourse analysis approach, this will be illustrated in the case of periphery constructions in Estonian national print media.
\end{abstract}

KEY WORDS Discursive peripheralization, rural peripheries, critical discourse analysis, Estonia

The ongoing discussions on the development (non-)potentials of rural peripheries illustrate the continuous treatment of rural and peripheral as two sides of the same coin. Despite both terms often being used interchangeably or occurring together, this equation is not self-evident. Research on rural representations including the critical debates on the social construction of peripheral ruralities and peripheralities (Cloke 2003; Cloke et al. 2006; Copus 2001; Halfacree 2007; Paasi 1995), followed by a series of empirical studies (Balogh 2015; Burdack et al. 2015; Miggelbrink and Meyer 2015; Timár and Velkey 2016; Plüschke 2015; Pospěch 2014; Steinführer 2015, and others), have scrutinized the rural and called its predominant association with the peripheral into question. As the cultural turn in social sciences revealed, such ascriptions are neither innocent nor neutral (Lefebvre 1974; Meyer and Miggelbrink 2013). On the contrary, by manifesting a hierarchical dichotomy of urban centres and rural peripheries, the equation is consequential. Guiding our thinking of and acting in space, it can impede future development perspectives (Beetz 2008) - a dynamic that has been well illustrated in the case of residential decision-making (Kährik et al. 2012; Ley in Cloke 2003).

By attempting to unravel the discursive node, the focus of this article is to deconstruct the underlying binary. Hence, the question of central concern is how these two discourses meet. In order to address this, I will first argue for overcoming the urban-rural divide inherent in geographical and sociological research by introducing discursive peripheralization as a conceptual framework, which allows for the analysis of socio-spatial inequalities and

Sociální studia / Social Studies 2/2016. Pp. 11-28. ISSN 1214-813X. 
their emergence on and between different scales. With its focus on the discursive dimension, the concept also offers an alternative to dominant structuralist approaches (Lang 2013). Subsequently, it will be explored how rural areas are not only represented, but also constituted as peripheries within a hegemonic discourse that naturalizes the ascription of development (non-)potentials. Following a critical discourse analysis approach and applying quantitative as well as qualitative content analysis, this will be illustrated on the example of periphery constructions in opinion columns in the Estonian national print media.

\section{Overcoming the Urban-Rural Divide: The Concept of Disc ursive Penipheralization}

When analyzing how rural areas become associated with peripheries, a constructivist take focusing on representations of rurality seems promising at first, as it goes beyond dominant structuralist approaches which take the urban-rural dichotomy for granted. But it also quickly reveals its limitations by being embedded in an urban-rural divide prevailing in sociological and geographical research, which reinforces the same binary under study. Bourdieu (1991) and Gregory (1994) have pointed out the crucial influence such categorizations have on our imagination of society and space. Moreover, based on post-colonialist and feminist studies, as well as recent debates on positionality (Koobak and Marling 2014; Suchland 2011; Stenning and Hörschelmann 2008; Tlostanova 2012), Blondel (forthcoming) calls for critically scrutinizing our theoretical frameworks and methods of inquiry so as to avoid the reproduction of hegemonic divisions in space. Following this line of argumentation all the way through also means crossing the established boundaries of the disciplines.

For bridging this prevalent divide, the concept of peripheralization introduced by Keim (2006) seems particularly promising. With its emphasis on socio-spatial polarization, it moves away from fixed categories and allows us to analyze the emergence of inequalities independent of scales and types of space (Fischer-Tahir and Naumann 2013; Lang et al. 2015). The geographical notion of peripheries as being "situated on the fringe" and "determined by their distance to a centre" (Kühn 2015: 2) already implies a relational and hierarchical understanding of spatial divisions that does not necessarily have to be confined to an urban-rural divide. Going beyond that, by combining theories of economic polarization, social inequality and political power, peripheralization shifts the focus to the multi-dimensional and multiscalar processes by which this relational hierarchy evolves and the types of space it is applied to (Kühn 2015; Lang et al. 2015). Hence, it urges us to question the widespread linking of peripheries with rural areas and the dynamics producing this link in practice (Fischer-Tahir and Naumann 2013; Keim 2006; Lang et al. 2015; Leibert 2013; Kay et al. 2012; Naumann and Reichert-Schick 2013). Moreover, by focusing on common mechanisms of marginalization, this perspective also opens up room for making urban concepts as territorial stigmatization fruitful for rural sociology (Benedek and Moldovan 2015).

In opposition to Kühn (2015), who excluded the communicative dimension from his analysis, the article seeks to reemphasize the discursive level. What is more, it conceptualizes discourses as inherent parts of peripheralization due to their mutually reinforcing links with practices and materialities (Meyer and Miggelbrink 2013). Following a Foucauldian understanding, 
they are not seen as representative for, but rather as constitutive of socio-spatial processes. Discourses are at the same time embedded in and co-constitutive of societal power relations. On one hand, they institutionalize widely recognized interpretations of social reality, thereby defining and limiting what can legitimately be expressed about certain topics (Jäger 1999; Schwab-Trapp 2006). On the other hand, access to resources and positions of power determines who has the right to speak and be heard in the discourse, hence, whose constructions become temporarily fixed through hegemony and manifested in symbols, categories and institutional practices (Bourdieu 1991; Jäger 2008; Paasi 2010; Spivak 1988). Despite being enwrapped in power relations, discourses can be understood as structuration processes that are always in becoming and therefore never complete or all-encompassing (Pred 1984). This means that while disabling certain forms of agency, they also enable others. Consequently, not only central but also peripheral actors potentially have the agency to speak in discourses, although to a different extent. This also implies the possibility of counteracting hegemonic with alternative discourses.

Due to the mutual relation of discourses and power, a consequent discourse analytical approach needs to go beyond the representational level and focus on the performativity of knowledge production (Jäger 1999), hence, in this case on the question how the peripheral is discursively linked to the rural and subordinated to the urban, by whom and with what consequences? The emphasis on the socio-historical conditions of textual production also assists in combating what Timár and Velkey (2016: 321), relying on Woods (2010), term the "dematerializing effect of the cultural turn". By analyzing the discursive structure, as well as the discursive field and its interpreting coalition, this approach deconstructs strategies of knowledge universalization as well as the conditions leading to its acceptance or rejection (Bourdieu 1991; Schwab-Trapp 2006).

Through the reemphasis on the so-called communicative dimension, I have proposed discursive peripheralization as a concept for analyzing the widespread link between the rural and the peripheral. By shifting the focus to the emergence of hierarchical categorizations embodied in space, this concept helps to overcome the urban-rural divide prevalent in sociological and geographical research. As a processual approach, it stresses the social constructivist nature of socio-spatial divisions, which are not only materially but also discursively (un-)made. Moreover, taking the discursive dimension seriously, it goes beyond the representational aspects and focuses on the way discourses are embedded in and constitutive of social reality. Discursive peripheralization therefore follows a relational, multi-dimensional and multi-scalar conception of socio-spatial polarization and accentuates the performativity of discourses, which are seen as an inherent part of peripheralization processes.

\section{More than J ust Representations: A Cnitical Discourse Analysis Approach}

The making of rural peripheries is explored using the critical discourse analysis approach developed by Jäger (1999), who bases his work on Foucault (1999) and Link (1982). Concerning the discursive structure, the focus lies on scrutinizing discursive nodes and strategies in order to understand what can legitimately be expressed about peripheries. Whereas the basic units of analysis are statements (discursive fragments) derived from print media articles, the analysis itself points beyond these individual texts (Foucault 1999). These 
statements are scrutinized for common patterns with special focus on the depiction of peripheries and the topics and stories associated with them. Thereby, fragments referring to the same subject are identified and bundled into main discursive threads. The entanglements between these threads resemble discursive nodes that link different discourses with one another creating a discursive effect by which particular interpretations of social reality (truth claims) are constituted as universalized knowledge (Jäger 1999).

The universalization of truth claims is further fostered by discursive strategies, which can be separated into those regulating participation in the discourse and those drawing limits to the content and ways of legitimate expression (Foucault 1999; Schwab-Trapp 2006). The regulation of authorized languages and speakers guarded by discourse societies is a central strategy of exclusion from the discourse as it determines who has the right to speak, when, where and how (Bourdieu 1999; Foucault 1999). Within the discourse, legitimization strategies play a crucial role for hegemonizing truth claims. Common tactics are to depict particular interpretations of social reality as the only alternative or to relativize the risks involved in it (Jäger 1999; Schwab-Trapp 2006). This strategy goes hand in hand with strategies to silence or delegitimize alternative voices by either neutralizing their objections, denying the relevance of their claims or excluding them from the discourse altogether (Jäger 1999; Schwab-Trapp 2006). However, the stabilization of knowledge through the so-called repetition effect figures most prominently (Foucault 1999). Therefore, a frequency analysis of repeated statements and discursive links takes a prominent place in the analytical framework.

Concerning the discursive field, the contextualization of the discourse and the identification of interpreting coalitions are central. Schwab-Trapp (2006), relying on Bourdieu (1991), characterizes discursive fields as public arenas for competing truth claims. Showing a specific spatiality and temporality, they define the prevalent instruments of and access to power, as well as the rules of engagement that discourse participants must follow to successfully make their claims heard. Hence, the regulation of participation in the discourse and the value of individual contributions are field-specific, including the field of journalism, which is of primary interest here (Jäger 1999; Schwab-Trapp 2006). In practice, the rules are enforced by so-called "discourse societies" (Foucault 1999). While institutionalized entities, for example publishers or editors, control the access to and distribution of discourses, communities supporting a specific truth claim regulate discourses internally by defining the rules for expression (SchwabTrapp 2006). Bürk et al. (2012: 339) call the latter an "interpreting coalition" that plays a key role in disseminating discourse positions, defined as ideological standpoints guiding the contribution to and evaluation of discourse formations (Jäger 1999). Coalitions develop discursive strategies and nodes, which become naturalized by other authors who regularly refer to them as authorities when either showing consensus or a deviating discourse position.

\section{(Un-)Making Rural Peripheries: Dec onstruction of a Public Disc ourse}

The conceptual and analytical framework is illustrated in the case of public discourses on the "periphery" in Estonia. Due to their ongoing material deprivation and territorial stigmatization, rural areas in post-Soviet space are generally confronted with an overlapping discursive peripheralization by being displayed on the downside of the centre-periphery, 
urban-rural and west-east divide (Kay et al. 2012). On one hand, rural areas and their inhabitants in Estonia similarly face a particularly negative image as peripheral, passive, marginalized and somehow different (Annist 2011; Nugin 2014; Trell et al. 2012). As shown in former studies, in the Central and Eastern European context this othering process on a normative development scale is a multi-scalar one, affecting the national, regional and local levels alike (Annist 2011; Koobak and Marling 2014; Suchland 2011; Timár and Velkey 2016; Tlostanova 2012). On the other hand, this negative discourse is met with romanticizing notions of the rural as a traditional and wholesome way of life that figure prominently in Estonian identity discourse (Nugin 2014; Plüschke-Altof 2015). This concurrence of images of decline and rural idyll has also been ascertained in other cases (Juska 2007; Pospěch 2014; Shucksmith et al. 2009).

Until now, with few exceptions (Annist 2011; Kährik et al. 2012; Nugin 2014; Pfoser 2014; Sooväli 2004; Trell et al. 2012; Virkkunen 2002), spatial discourses have rarely been researched in the Estonian case. As such discourses are co-constitutive of socio-spatial polarization and the politics involved in it, a closer look at how the discursive link between rural and peripheral is established, by whom and with what consequences, seems crucial. This is what this article aims to do through the exploration of freely available online articles in the Estonian daily Eesti Päevaleht and the weekly newspaper Maaleht, which were chosen due to their specific discourse positions. Whereas the focus of the latter is explicitly on rural issues, the former rather concentrates on the concerns and perspectives of urban readers. Both are among the newspapers with the widest circulation and the most frequently visited websites (Balčytienè and Harro-Loit 2009; EALL 2016; Eurotopics 2016). Since the continuous expansion of internet access, the online versions have become ever more important. Due to their widespread readership, high degree of interactivity and considerable overlap with the printed version, Balčytienè and Harro-Loit (2009) identify them as national discussion forums or, following the conceptual framework above, as a public arena for competing truth claims. Using the keywords äärema* and perifeer* (roots of the word periphery in Estonian) in the time period between January 2011 and December 2015, altogether 126 online articles were retrieved from the opinion columns (arvamus) of both papers and subsequently subjected to analysis.

\section{Reproducing Rural Peripheries: A Hegemonic Discourse}

On the basis of these articles, an initial frequency analysis of topics and places associated with the term "periphery" was conducted in order to understand how rural areas and peripheries are discursively linked. The exploration of discursive threads (Figure 1), hence fragments referring to the same subject, reveals core-periphery relations as a crosscutting theme that mirrors current political issues. Among them were the municipal (2013) and parliamentary elections (2015) as well as the global financial and European debt crisis, but also the military conflict in Crimea.

The threads also illustrate the multi-scalar, multi-dimensional and processual nature of peripheralization. On the European and international scale, peripheries were mainly discussed in the light of an unequal distribution of burdens and risks in the European Union as well as with regard to subordination or dependence (together $18.5 \%$ ), foremost in the case 
of Estonia as formerly colonized by Russia and currently dependent on the European Union. On a national and regional scale, the initiation of local development projects as a coping strategy was debated $(2.5 \%)$, but also different aspects of peripheralization, including limited access and mobility, demographic shrinkage and socio-economic decline (together $18 \%$ ). These translate into a spatial polarization that appears to be most pronounced between urban and rural areas, as the outstanding role of rural peripheralization illustrates, which resembles the main topic of around $15 \%$ of the 126 articles. In contrast, peripheralization in the urban context was discussed to a much lesser extent (1.5\%).

Figure 1: Discursive threads

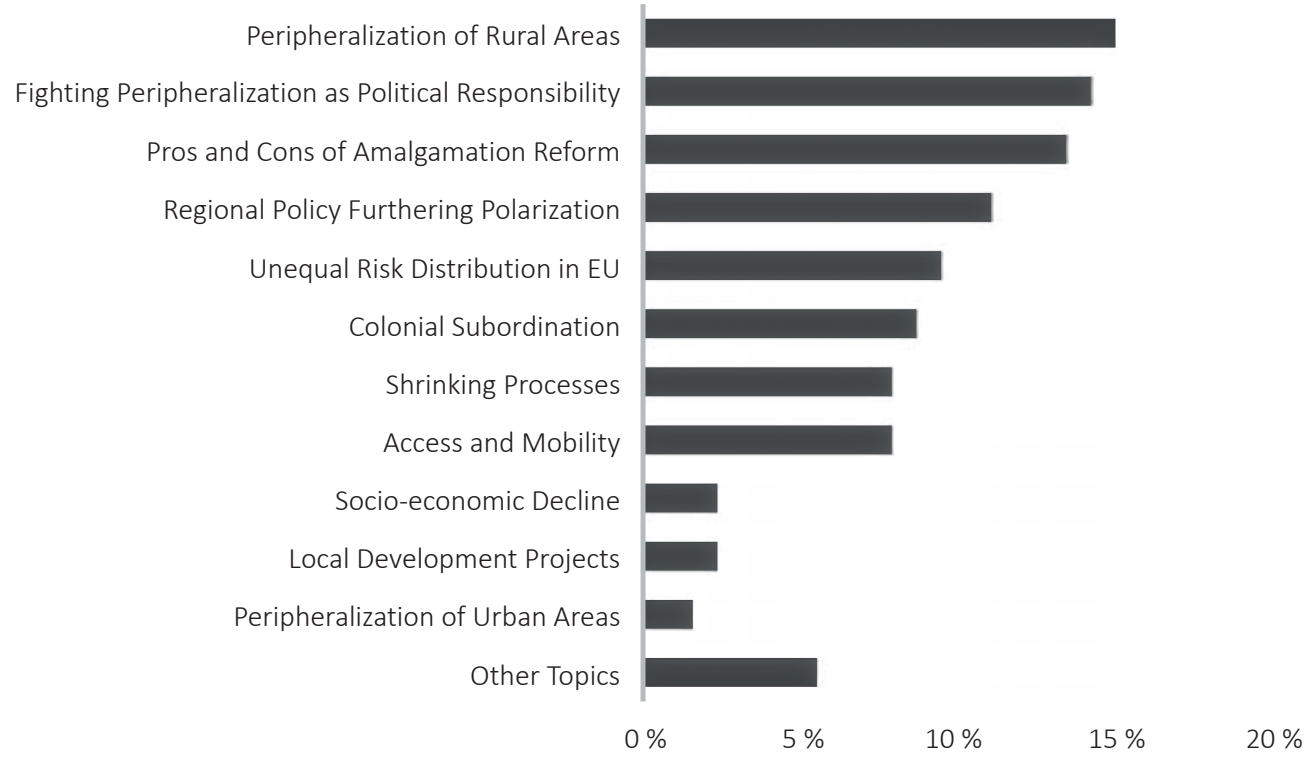

Source: Illustration based on the author's calculations of topics associated with peripheries in Eesti Päevaleht and Maaleht (2011-2015)

These discussions occur against the backdrop of rising socio-spatial inequalities that take the form of rapid sub-/urbanization while, simultaneously, peripheralization processes in small towns and on the countryside deepen (Juska 2007; Lang et al. 2015; Leetmaa et al. 2015; Smith and Timár 2010; Statistics Estonia 2009/2015). The reasons for this development are often seen in the transformation process since regaining independence in 1991, which focused on rapid market-economy reforms and was accompanied by a deep "distrust in everything created by the old regime" (Nugin 2014: 59). Built on a neoliberal development paradigm and success-oriented transition culture, Estonian policy has ever since promoted market liberalism free of state intervention (Lauristin and Vihalemm 2009; Madariaga 2010). At the European Union level, this was supported by a general turn towards regional competitiveness and economic growth (Bristow 2005). 
In consequence, rural areas were subjected to multiple changes. The desire to break with existing institutional structures lead to the dissolution and privatization of collective farms (kolkhozes) in order to restore the single-farm production scheme of the interwar period, which soon proved to be uncompetitive and was therefore substituted by large-scale farming (Nugin 2014). But it also resulted in a devaluation of egalitarian norms dismissed as socialist in nature and replaced by individualism and consumerism (Juska 2007). Due to this restructuring and a general post-productivist trend, the population share involved in agriculture dropped rapidly. While this also offered new opportunities for a diversification of income opportunities in the countryside, it initially caused increasing poverty rates and a downward spiral of rural peripheralization. Therefore, the question to what extent the Estonian government(s) can and should be held responsible for causing peripheralization (11\%) and dealing with it (14\%) was a topic of intense discussion.

As rural inhabitants have consequently been compelled to relocate or commute to urban areas in order to alleviate poverty risks, there has been a continuous demographic shrinkage. As a result, rural municipalities and small towns have been under immense financial and political pressure (Leetmaa et al. 2015), leading to a debate on their capacity and the call for an administrative reform that redefines the municipal borders established at the beginning of Estonian re-independence. This debate is mirrored in $13.5 \%$ of the articles, which focus on the pros and cons of an administrative reform.

An urban-rural divide in core-periphery relations is also supported when scrutinizing where peripheries are discursively located by the authors (Figure 2). Which concrete

Figure 2: Discursive localization of peripheries

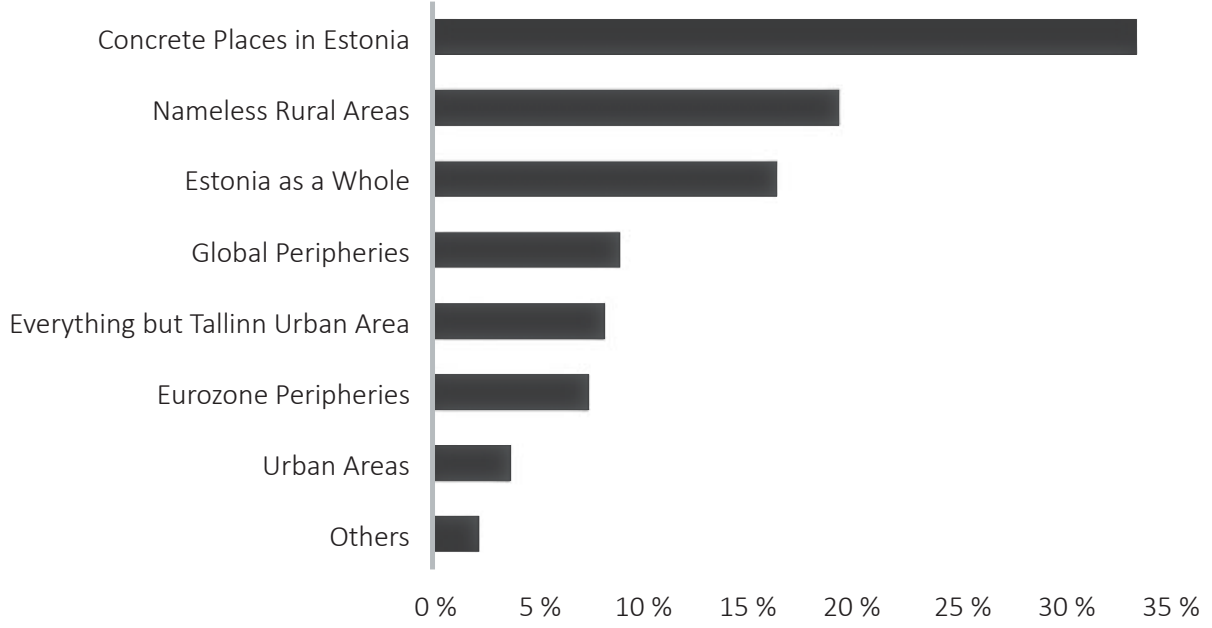

Source: Illustration based on the author's calculations of places associated with peripheries in Eesti Päevaleht and Maaleht (2011-2015) 
places do they mention or report about when discussing peripheries and peripheralization? Altogether, rural areas appear in three different ways. Firstly, via placing peripheries in concrete places in Estonia (34 \%) that are to a large extent rural. Secondly, by locating them in "nameless" rural areas that are not further specified (19\%). In contrast, reports on urban peripheries only account for about $4 \%$ of the cases, but these are clearly named. Thirdly, by declaring everything a periphery that is not part of the centre, which in most cases means the capital city Tallinn, its suburbs and the surrounding Harjumaa County (8\%). Even if the rest also includes other cities and small towns, this opposition mainly draws on an urbanrural hierarchy. Most of the cases placing peripheries in nameless rural areas and in opposition to the Tallinn urban area occur in Eesti Päevaleht, whereas the rural weekly Maaleht rather focuses on concrete places. The localization of peripheries in the European (specifically the Eurozone) and international contexts accounts for $16.5 \%$ of the articles. Estonia as a whole is most prominently discussed as a periphery of the European Union, in world politics or the global market (16\%), reflecting its multiple dependencies on the one hand and processes of self-colonization on the other hand (Tlostanova 2012).

Due to this repetition effect, a strong association of the peripheral with the rural is manifested. While giving a first overview of the association of the peripheral with the rural, a solely quantitative approach also has its limits as it cannot show how the link is discursively produced and what the notion of periphery exactly entails. Therefore, a qualitative content analysis was added, focusing on discursive nodes evolving from these threads and on the strategies connecting both of them. In the discourse under scrutiny, the term "periphery" functions as a floating signifier that tends to absorb different meanings projected on it and is therefore susceptible to political use (Laclau 1996). Depending on the discourse position of the authors, representing either the hegemonic or counter-discourses, peripheries and their specific features are interpreted in a different light, which will be illustrated with the help of Figure 3.

As the word cloud demonstrates, the hegemonic discourse presents peripheries above all $(25.5 \%)$ as places that are lagging behind (mahajäänud). In a story of decline (kahanemine), the difficult socio-economic situation characterized by missing employment opportunities (töökohtade puudumine), decreasing wages (langevad palgad) of the working poor and increasing impoverishment (rahva vaesumine) is seen as the cause of massive losses (suured kaotused) of population, leaving peripheries empty (10\%) or deserted (inimtühi). Moreover, peripheries are depicted as institutionally thin $(6 \%)$ in a narrative of incapacity that first of all reduces the role of local governments to a question of the administrative capacity to provide public services as well as technical and social infrastructure. This is then accompanied by reports on incidents of incapacity, for example in financing specialists or providing adequate service quality.

Both notions of peripheries appear to favour the urban while constituting the rural as periphery per se. This shows up not only in the noticeable number of cases that directly equate peripheral with rural $(4.5 \%)$, but also in the discursive nodes tying the socio-economic and political understanding of peripheries to the geographical. Particularly, vanishing economic performance as well as demographic shrinkage are related to notions of peripheries as distant, remote (kauge, $4 \%$ ) and inaccessible (kättesaamatu, $3 \%$ ). This link between 
Figure 3: Discursive nodes

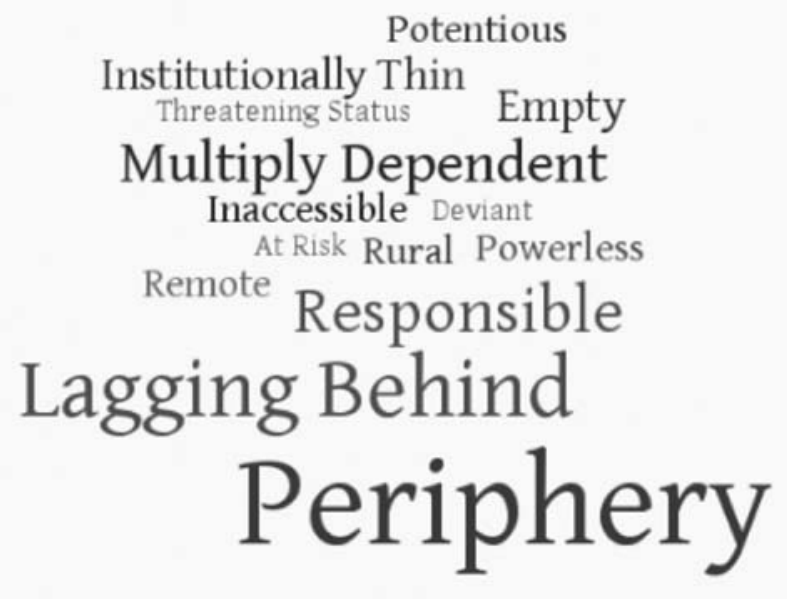

Source: Illustration via worditout.com based on the author's calculations of features associated with peripheries in Eesti Päevaleht and Maaleht (2011-2015): Lagging Behind (25.5\%), Responsible (18\%), Multiply Dependent $(15.5 \%)$, Empty (10\%), Institutionally Thin (6\%), Rural (4.5\%), Powerless (4\%), Remote (4\%), Potentious (4 \%), Inaccessible (3\%), Deviant (2\%), Threatening Status (2 \%), At Risk (1.5\%)

economic and geographical indicators of peripherality was also identified by Bristow (2005/2010) and Shearmur (2012) as a strategy of objectifying development and innovation deficits, thereby reinforcing an opposition of prosperous and strong urban centres versus poor and weak rural peripheries. Compiled into indexes and rankings, these are also used to find out "who is winning" (Bristow 2005: 286) or which are Estonia's "successful" (Statistics Estonia 2009) and "strong municipalities" (Kaukvere 2014). But also the narrative of incapacity is linked to geographical notions of smallness and low population density that are characteristic of rural areas. The missing revenue base (tulubaas) of municipalities resulting from the low population density is then used to explain this lack of capacity. Both of these nodes tend to culminate in the arguments of amalgamation reform proponents, in which economic effectiveness and political capacity are combined to legitimize further centralization as a way of fighting peripheralization. Tied by a discursive node, this interpretation of geographical peripheries as lagging behind and politically incapable creates a discursive effect by which the spatially biased understanding of development becomes universalized.

Another important discursive node revolves around the question of responsibility for the causes and ways of dealing with peripheralization (18\%). Peripheralization is depicted as a process which can be deepened or reversed by those in charge. Who those in charge are or where they could be sought, at European Union, national or local levels, depends on the discourse position. Some authors shift the responsibility for the causes of peripheralization to 
the inhabitants themselves by portraying them as resistant to development, narrow-minded and socially pathological. Whereas the depiction of social pathologies, such as crime and alcoholism, occurs mainly in relation to urban peripheries, narrow-mindedness is attributed to Estonia as a whole. In contrast, resistance to development is presented as a rather rural issue. As indicated in studies on territorial stigmatization (Bürk et al. 2012; Wacquant et al. 2014), this depiction of peripheral inhabitants as deviant (2\%) is used to enforce one's own development path by presenting peripheralization as result of the continuation of such deviant behaviour. Authors, for example, warn of locked-in situations (muidu keerame lukku) or the neutralization of fast development opportunities (kiire arengu võimalused neutraliseerima). In comparison to the debate on the so-called second Estonia (teine Eesti) as "loser" of the transformation period, which emerged at the beginning of the 2000s (Lauristin and Vihalemm 2009), stigmatization strategies depicting residential pathologies account for only a minority of cases in the period of analysis (2011-2015). This focus shift from residential stigmatization to regional development capacities in the course of (post-) EU accession has also been confirmed in other cases (Juska 2007).

\section{De-penipheralizing Ruralities: Altemative Discourses and Counter Strategies}

It is around this question of responsibility and the depiction of peripheries as lagging behind that the two different counter-discourses evolve. As the work of Meyer and Miggelbrink (2013) shows, peripheries are constructed not only by the centres, but also by people facing moments of peripheralization. By actively relating to hegemonic discourses and value-laden ascriptions, actors negotiate the meaning of and their own position in the centre-periphery hierarchy. Accordingly, discursive attempts to de-peripheralize rural areas draw on the discursive nodes established in the hegemonic discourse.

Based on the equation of the peripheral with the rural, the first counter-discourse or reversal strategy relies on the two contradictory constructions of rurality, which Shucksmith et al. (2009: 1277) term "modernist" and "pre-modernist" narratives. Whereas the former associates rural with "backwardness", emphasizing the lag in progress and development in comparison to urban areas, the latter creates a rural idyll (Halfacree 2006) and builds on the notion of strategic essentialism (Jacobs 1996). These dichotomous constructions of rurality are also present in the Estonian media discourse, but the latter tends to be strategically employed in order to flip the urban-rural hierarchy on its head. Therefore, on one hand, romanticized images of the rural are attached to places labelled as peripheries by referring to the national identity construction of Estonians as country people (maarahvas), emphasizing the role of rural areas for the authentic preservation of folk culture (pärimuskultuur) and highlighting their peace and quiet (rahu ja vaikus). This is then opposed to cities negatively stereotyped as hostile living environments, from which people flee as from a horrible accident (nagu põgeneks hirmsa õnnetuse eest). On the other hand, stories of active coping efforts are employed to avert the blame for ongoing peripheralization processes that has been shifted to peripheral inhabitants by portraying them as passive and development-resistant. Here, local residents are described as hard-working and courageous - a tendency that has already been observed in previous studies (Nugin 2014). 
However, the reversal strategy is deeply embedded in the hegemonic discourse, hence enforces the norm rather than resists it (Bürk et al. 2012). Nugin (2014) and Kay et al. (2012: 58) point out that the construction of national identity through rural idyll and "romanticized folk cultures" already played an important role in discursively resisting Soviet industrialization and urbanization attempts and continues to be employed against centralization policies today. But the resulting debate on peripheral potentials (4\%), which usually focuses on place-marketing and tourism as soft development factors, also builds on this established rural idyll in order to discuss its possible means of commodification. Fischer-Tahir and Naumann (2013) therefore argue that the latter is deeply embedded in the logic of competitiveness, separating winners from losers, whereby the winners are those who best adjust to neoliberal norms. It also tends to focus on satisfying an urban gaze on rural areas (Kobayashi and Westlund 2013). Moreover, coping efforts are commonly presented as neoliberal success stories (edulugu) that come into being by encouraging entrepreneurship and growth, and are then statistically objectified via rankings and league tables.

In contrast, the second counter-discourse critically scrutinizes the underlying norms that the centre-periphery hierarchy relies on. By describing them as threatening status ( $2 \%)$, the authors shift the focus from peripheries as lagging behind (mahajäänud) to places being deliberately left behind (mahajäetud). Hence, they seek to replace the story of decline by a story of loss ever since the beginning of transformation, which saw the downgrading of collective farms and mono-functional settlements (monoasulad) as former centres to today's peripheries. By asking "what kind of development and for whom" (Pike et al. 2007: 1253), this norm-rejection strategy questions the objectives of Estonian regional policy, which is presented as focusing solely on efficiency (tõhusus) and cost-savings (kokkuhoid). The project-based regional policy is furthermore criticized by equating its outcomes with unnecessary investments made during the era of Soviet regional planning. In the same vein, amalgamation reform opponents often compare municipality mergers to Soviet centralization policy that drew lines on a map with a ruler (maakaardile joonlauaga jooni vedama). Hence, reference to the domination by "the Soviet other" (Kay et al. 2012: 57) is strategically employed against current regional policy trends.

A critical stance towards Estonia's regional policy also plays a pivotal role in discourses countering the depiction of peripheries as institutionally thin. Here, the story of incapacity is confronted with a story of political neglect and powerlessness $(4 \%)$, hence, the inability to be capable. The reduction of the role of local governments to a question of service provision is opposed by reemphasizing their democratic counterweight function in a centralized state. It is argued that they are more transparent (läbipaistvam) and actively fight the risk of a disenchantment with democracy on the part of peripheral inhabitants, whose powerlessness is vividly compared to being run over with a steamroller (sõidetaks teerulliga üle). Both the story of loss and the story of neglect resemble instances of trying to shift the responsibility for the causes and ways of dealing with peripheralization back to the centre. Whereas both newspapers offer room for counter-discourses, the demand that the national government assumes responsibility is especially pronounced in the rural weekly Maaleht.

In the same vein, the reference to the multilevel dependence (sõltuvus) of peripheries (15.5\%) takes the stories of loss and lack of capability to a European and international level 
by referring to the unequal risk distribution in the European Union and colonial subordination. The authors criticize various dimensions of political, economic, cultural and psychological dependence, pointing to a "global coloniality" (Tlostanova 2012: 130) that has also been discussed in prior studies (Annist 2011; Koobak and Marling 2014; Suchland 2011). Moreover, the reference to overarching global and regional dependence is also employed to counteract the political neglect of peripheries and initiate a change in regional policy. In one line of argument, demographic shrinkage is, for example, attributed to a failure of regional policy and then linked to issues of national defence. Creating a doom scenario, peripheries are thereby presented as being at military risk (1.5\%), which against the backdrop of Estonia's colonial history could also pose a national security threat. By asking how national defence should be organized if the number of men capable of carrying a gun is declining in peripheral municipalities (kui püssi kanda jaksavate meeste hulk ääremaalistes valdades kahaneb), the protection of peripheries is connected to the protection of the nation as a whole.

In summary, the equation of the peripheral with the rural holds true for the Estonian case. This becomes apparent in the main discursive thread "rural peripheralization" and the discursive placement of peripheries in rural areas. But there is also a remarkable resemblance in the structure of peripheralization and rurality discourses as exemplified by the analysis of discursive nodes. Filling the term "periphery" with a meaning of rural places that are lagging behind, institutionally thin, empty, remote, and inaccessible, turns the established equation into a rural subordination. As discourses are consequential, this means that the perceived features of peripheries in general get shifted to rural areas in particular. Through the portrayal of peripheral inhabitants as deviant, some authors link this subordination to the question of responsibility and shift the blame for socio-economic problems to the residents themselves. The counter-discourses revolve around these discursive nodes by reversing the established urban-rural hierarchy and by rejecting dominant neoliberal norms in order to shift the question of responsibility back to the centre.

\section{Intellectual, Central, Male: The Interpreting Coalition}

When looking at the advocates of these different positions, it becomes clear that even if the freedom of press in Estonia is considered particularly high (Freedom House 2016), which implies a rather non-discriminatory access to the public arena, the discourse is dominated by an interpreting elite. This elite consists mainly of journalists (33\%), politicians (20\%), academics (18\%) and artists (10\%). Less often, the articles are authored by readers, representatives of interest groups, entrepreneurs or consultants (together $19 \%$ ). Moreover, there is a noteworthy gender gap as only about $10 \%$ of the contributions can be attributed to female authors - a trend that has been observed for the opinion columns in Estonian newspapers in general (Eurotopics 2015). While the authors were categorized according to the institutional affiliation ascribed to them in the articles, a common overlap of positions occupied by members of the Estonian elite should be mentioned. The authors often assume important roles in several fields, hence, are not only participating in public discourse but also actively engaging in the politics and economics revolving around it. 
The majority of contributors represent newspaper publishers, state bodies, research and cultural institutions, as well as consultancies and for-profit organizations located in the capital city of Tallinn and the university city of Tartu. Only a minority, mainly consisting of readers, rural interest group representatives and municipality leaders, is located in areas labelled as peripheries. They are the main proponents of the stories of economic loss and political incapacity as well as the rural idyll. In contrast, advocates of the hegemonic discourse can be found more among the central elite. Objectification of development (non-)potentials and discussions on commodification opportunities can be found at both ends of the spectrum, indicating a deep embeddedness in the neoliberal system.

In accordance with Bürk et al. (2012) it can be concluded that while the Estonian discourse on peripheries is distributed to a wide audience, it is regulated by a small elite that also has the potential to influence the practices and materialities of peripheralization. Despite the dominance of actors from the centre, local politicians and inhabitants also participate in the discourse, but to a lesser extent.

\section{Tying and Unravelling the Disc ursive Node: Competing Thuth Claims}

Building on the concept of discursive peripheralization and based on critical discourse analysis, this article has scrutinized the discursive link between the rural and the peripheral. By deconstructing current discourses on peripheries in the Estonian daily newspaper Eesti Päevaleht and the rural weekly Maaleht, it has shown how the peripheral is equated with the rural through the discourse on peripheralization in general and rural peripheralization in particular. This link is further strengthened by placing peripheries in concrete and nameless rural areas or by the opposition of the Tallinn urban region to the rest of Estonia. Through the repetition effect, the association of the peripheral with the rural creates a discursive effect by which the ascribed features of peripheries as lagging behind, institutionally thin, remote, inaccessible, multiply dependent and deviant are transferred to rural areas in general. Stories of peripheral decline and incapacity combined with objectification of development deficits and, to a lesser extent, stigmatization strategies universalize this particular interpretation of peripheries and are also employed to legitimize a certain development path as the only viable alternative.

Referring to these established discursive nodes, counter-discourses oppose stories of decline and incapacity with stories of loss since the beginning of transformation as well as political neglect and powerlessness. Also, reversal strategies rely on this established urban-rural hierarchy when they try to turn it on its head by attaching positive images to peripheries via the creation of a rural idyll and the reference to national identity constructions. Moreover, by pointing out the parallels between Soviet regional planning as the policy of a former colonizer and current regional policy embedded in overarching global and regional dependencies, peripheries are presented as being at risk and their fate is connected to the fate of the Estonian state as a whole. This leaves the government with no alternative but to fight peripheralization. Altogether, the analysis of discursive nodes and strategies reveals a remarkable similarity between peripheralization and rurality discourses, hence indicating the deep-rootedness of the equation of the rural with the peripheral. 
By deconstructing these different discourse positions, this article has shown opposing attempts to tie and unravel a discursive node that links peripheries with rural areas. As these discourses take place against the same backdrop, they can be interpreted as competing processes of knowledge production that do not only represent, but also constitute social reality and attempt to universalize particular truth claims. This reassures the importance of contextualizing the circumstances under which discourses become performative. By following Meyer and Miggelbrink (2013) in re-shifting the focus to discursive agency, the analysis has included an identification of the interpreting coalition of core-periphery relations in Estonian media discourse. In order to not only understand how this discursive node is tied, but also how it shows consequences in practice, an analysis of the power structures constituting discursive fields could be a fruitful attempt for future studies. Therefore discursive peripheralization has been introduced as a conceptual framework that allows us to analyze the (re-)production of centres and peripheries, or in this case, the urban and the rural.

\section{Acknowledgement}

I would like to thank Aet Annist and Andres Kuusik as well as both reviewers for their helpful comments on earlier drafts of this paper. The research leading to the results presented in this article was conducted within the framework of the project "Socio-economic and Political Responses to Regional Polarization in Central and Eastern Europe" $\left(\mathrm{RegPol}{ }^{2}\right)$, coordinated by the Leibniz Institute for Regional Geography in Leipzig, Germany. The project received funding from the People Program (Marie Curie Actions) of the European Union's Seventh Framework Program FP7/2007-2013/ under REA grant agreement $n^{\circ} 607022$.

\section{References}

ANNIST, Aet. 2011. Otsides kogukonda sotsialismijärgses keskuskülas. Arenguantropoloogiline uurimus. Tallinn: ACTA Universitatis Tallinnensis.

BALČYTIENĖ, Auksè and Halliki HARRO-LOIT. 2009. "Between Reality and Illusion: Re-Examining the Diversity of Media and Online Professional Journalism in the Baltic States." Journal of Baltic Studies 40(4): 517-530.

BALOGH, Péter. 2015. "The Land of Storms and the Region Where the Country's Heart Beats: Changing Images of Peripherality in Hungary.” Hungarian Geographical Bulletin 64(3): 219-231.

BEETZ, Stephan. 2008. "Peripherisierung als räumliche Organisation sozialer Ungleichheit.” Pp. 7-16 in Peripherisierung: Eine neue Form sozialer Ungleichheit?, edited by Eva BARLÖSIUS and Claudia NEU. Berlin: Berlin-Brandenburgische Akademie der Wissenschaften.

BENEDEK, József and Aura MOLDOVAN. 2015. "Economic Convergence and Polarisation: Towards a Multi-dimensional Approach.” Hungarian Geographical Bulletin 64(3): 187-204.

BLONDEL, Cyril. Forthcoming. "How Can We Approach Peripheralisation Without Peripheralising? Decolonising (Our) Discourses on Socio-spatial Polarisation in Europe.” Environment and Planning D: Society and Space (under review).

BOURDIEU, Pierre. 1991. Language and Symbolic Power. Cambridge, MA: Harvard University Press. 
BRISTOW, Gillian. 2005. "Everyone's a 'Winner': Problematising the Discourse of Regional Competitiveness." Journal of Economic Geography 5(3): 285-304.

BRISTOW, Gillian. 2010. "Resilient Regions. Re-'Place'ing Regional Competitiveness.” Cambridge Journal of Regions, Economy and Society 3(1): 153-167.

BURDACK, Joachim, NADLER, Robert and Michael WOODS. 2015. "Rural Regions, Globalization and Regional Responses: The Case of Oberlausitz Region." Pp. 323-339 in Understanding Geographies of Polarization and Peripheralization, edited by Thilo LANG, Sebastian HENN, Wladimir SBIGNEV and Kornelia EHRLICH. Houndmills: Palgrave Macmillan.

BÜRK, Thomas, Manfred KÜHN and Hanna SOMMER. 2012. "Stigmatisation of Cities: The Vulnerability of Local Identities." Raumforschung and Raumordnung 70: 337-347.

CLOKE, Paul. 2003. Country Visions. London: Pearson Prentice Hall.

CLOKE, Paul, Terry MARSDEN and Patrick MOONEY, P. 2006. The Handbook of Rural Studies. London: SAGE.

COPUS, Andrew K. 2001. "From Core-periphery to Polycentric Development: Concepts of Spatial and Aspatial Peripherality." European Planning Studies 9(4): 539-552.

EESTI AJALEHTEDE LIIT (EALL). 2016. "EALL liikmeslehtede ja Ajakirjade Liidu väljaannete keskmised tiraažid.” Retrieved February 15, 2016 (http://www.eall.ee/tiraazhid/index.html).

EUROTOPICS. 2015. "Estonia's Female Journalists are Afraid of Opinions.” Eurotopics archive. Retrieved February 15, 2016 (http://archiv.eurotopics.net/en/home/presseschau/archiv/article/ ARTICLE168608-Estonia-s-female-journalists-are-afraid-of-opinions).

EUROTOPICS. 2016. “Media Estonia: Europe's Press Comments.” Retrieved February 15, 2016 (http:// www.eurotopics.net/en/142186/media).

FISCHER-TAHIR, Andrea and Matthias NAUMANN, M. 2013. "Introduction: Peripheralization as the Social Production of Spatial Dependencies and Injustice." Pp. 9-26 in Peripheralization: The Making of Spatial Dependencies and Social Injustice, edited by Andrea FISCHER-TAHIR and Matthias NAUMANN. Wiesbaden: Springer.

FOUCAULT, Michel. 1999. Botschaften der Macht. Der Foucault-Reader. Stuttgart: Deutsche Verlags-Anstalt.

FREEDOM HOUSE. 2016. “Estonia: Freedom of the Press 2015.” Retrieved February 15, 2016 (https:// freedomhouse.org/report/freedom-press/2015/estonia).

GREGORY, Derek. 1994. Geographical Imaginations. Cambridge, UK: Blackwell Publishers.

HALFACREE, Keith. 2006. "From Dropping Out to Leading On? British Counter-Cultural Back-to-the-Land in a Changing Rurality.” Progress in Human Geography 30(3): 309-336.

HALFACREE, Keith. 2007. "Trial by Space for a 'Radical Rural': Introducing Alternative Localities, Representation and Lives." Journal of Rural Studies 23(2): 125-141.

JACOBS, Jane M. 1996. “Authentically Yours: De-touring the Map.” Pp. 132-156 in Edge of Empire: Postcolonialism and the City, edited by Jane M. JACOBS. New York: Routledge.

JÄGER, Siegfried. 1999. Kritische Diskursanalyse. Eine Einführung. Duisburg: DISS.

JÄGER, Siegfried. 2008. "Zwischen den Kulturen: Diskursanalytische Grenzgänge.” Pp. 327-351 in Kultur - Medien - Macht: Cultural Studies und Medienanalyse, edited by Andreas HEPP and Rainer WINTER. Wiesbaden: Springer VS.

JUSKA, Arunas. 2007. "Discourses on Rurality in Post-socialist News Media: The Case of Lithuania's Leading Daily 'Lietuvos Rytas' (1991-2004).” Journal of Rural Studies 23(1): 238-253.

KÄHRIK, Anneli, Kadri LEETMAA and Tiit TAMMARU. 2012. "Residential Decision-Making and Satisfaction Among New Suburbanites in the Tallinn Urban Region, Estonia." Cities 29(1): 49-58.

KAUKVERE, Tiina. 2014. "Vaata, millised on Eesti võimekaimad ja nõrgimad omavalitsused." Postimees. Retrieved February 15, 2016 (http:/www.postimees.ee/2948519/vaata-millised-on-eesti-voimekaimad-ja-norgimad-omavalitsused). 
KAY, Rebecca, Sergei SHUBIN and Tatjana THELEN. 2012. "Rural Realities in the Post-socialist Space." Journal of Rural Studies 28(2): 55-62.

KEIM, Karl-Dieter. 2006. "Peripherisierung ländlicher Räume: Essay." Aus Politik und Zeitgeschichte 37: $3-7$.

KOBAYASHI, Kiyoshi and Hans WESTLUND. 2013. Social Capital and Rural Development in the Knowledge Society. Northampton: Edward Elgar Publishing.

KOOBAK Redi and Raili MARLING. 2014. "The Decolonial Challenge: Framing Post-socialist Central and Eastern Europe within Transnational Feminist Studies." European Journal of Women's Studies 21(4): 330-343.

KÜHN, Manfred. 2015 "Peripheralization: Theoretical Concepts Explaining Socio-Spatial Inequalities." European Planning Studies 23(2): 1-12.

LACLAU, Ernesto. 1996. Emancipation(s). London: Verso.

LANG, Thilo. 2013. "Conceptualizing Urban Shrinkage in East Germany: Understanding Regional Peripheralization in the Light of Discursive Forms of Region Building." Pp. 224-238 in Peripheralization: The Making of Spatial Dependencies and Social Injustice, edited by Andrea FISCHER-TAHIR and Matthias NAUMANN. Wiesbaden: Springer.

LANG, Thilo, Sebastian HENN, Wladimir SBIGNEV and Kornelia EHRLICH. 2015. "Understanding New Geographies of Central and Eastern Europe.” Pp. 1-24 in Understanding Geographies of Polarization and Peripheralization, edited by Thilo LANG, Sebastian HENN, Wladimir SBIGNEV and Kornelia EHRLICH. Houndmills: Palgrave Macmillan.

LAURISTIN, Marju and Peeter VIHALEMM. 2009. “The Political Agenda during Different Periods of Estonian Transformation: External and Internal Factors.” Journal of Baltic Studies 40(1): 1-28.

LEETMAA, Kadri, Agnes KRISZAN, Mari NUGA and Joachim BURDACK. 2015. "Strategies to Cope with Shrinkage in the Lower End of the Urban Hierarchy in Estonia and Central Germany." European Planning Studies 23(1): 147-165.

LEFEBVRE, Henri. 1974. 2002. "The Production of Space." Pp. 131-141 in The Spaces of Postmodernity: Readings in Human Geography, edited by Michael DEAR and Steven FLUSTY. Oxford: Blackwell.

LEIBERT, Tim. 2013. "The Peripheralization of Rural Areas in Post-Socialist Central Europe: A Case of Fragmenting Development? Lessons for Rural Hungary.” Pp. 101-120 in Peripheralization: The Making of Spatial Dependencies and Social Injustice, edited by Andrea FISCHER-TAHIR and Matthias NAUMANN. Wiesbaden: Springer.

LINK, Jürgen. 1982. “Kollektivsymbolik und Mediendiskurse.” kultuRRevolution 1: 6-21.

MADARIAGA, Aldo. 2010. "Mechanisms of Institutional Continuity in Neoliberal 'Success Stories': Development Regime in Chile and Estonia.” Köln: Max-Planck-Institute für Gesellschaftsforschung. Retrieved January 25, 2016 (http://www.econstor.eu/bitstream/10419/81130/1/766849341. pdf).

MEYER, Frank and Judith MIGGELBRINK. 2013. "The Subject and the Periphery: About Discourses, Loopings and Ascriptions.” Pp. 207-223 in Peripheralization: The Making of Spatial Dependencies and Social Injustice, edited by Andrea FISCHER-TAHIR and Matthias NAUMANN. Wiesbaden: Springer.

MIGGELBRINK, Judith and Frank MEYER. 2015. "Lost in Complexity? Researching the Role of Socio-Spatial Ascriptions in the Process of Peripheralization." Pp. 62-79 in Understanding Geographies of Polarization and Peripheralization, edited by Thilo LANG, Sebastian HENN, Wladimir SBIGNEV and Kornelia EHRLICH. Houndmills: Palgrave Macmillan.

NAUMANN, Matthias and Anja REICHERT-SCHICK. 2013. "Infrastructure and Peripheralization: Empirical Evidence from North-Eastern Germany.” Pp. 145-167 in Peripheralization: The Making 
of Spatial Dependencies and Social Injustice, edited by Andrea FISCHER-TAHIR and Matthias NAUMANN. Wiesbaden: Springer.

NUGIN, Raili. 2014. "'I Think that They Should Go: Let Them See Something': The Context of Rural Youth's Out-migration in Post-socialist Estonia." Journal of Rural Studies 34: 51-64.

PAASI, Anssi. 1995. "The Social Construction of Peripheriality: The Case of Finland and the Finnish-Russian Border Area." Pp. 235-258 in Competitive European Peripheries, edited by Heikki ESKELINEN and Folke SNICKARS. Heidelberg: Springer.

PAASI, Anssi. 2010. "Regions are Social Constructs, but Who or What 'Constructs' Them? Agency in Question.” Environment and Planning A 42(10): 2296-2301.

PFOSER, Alena. 2014. "Between Russia and Estonia: Narratives of Place in a New Borderland." Nationalities Papers 42(2): 269-285.

PIKE, Andy, Andrés RODRIGUEZ-POSE and John TOMANEY. 2007. "What Kind of Local and Regional Development and for Whom?" Regional Studies 41(9): 1253-1269.

PLÜSCHKE-ALTOF, Bianka. 2015. "Kolonisatoren von gestern, MitbürgerInnen von heute? Wandelnde Grenzziehungen gegenüber der russischen Minderheit in Estland." Pp. 347-381 in Tagungsband des 4. Studentischen Soziologiekongresses: Krisen, Prozesse, Potenziale, edited by Simon SCHOLZ and Julian DÜTSCH. Bamberg: University of Bamberg Press.

PLÜSCHKE, Bianka. 2015. "Visions of the Rural Impeding Development? Discourses on a 'Problematic' Region in Estonia." Conference Proceedings European Society for Rural Sociology Congress 134-135. Aberdeen: European Society for Rural Sociology.

POSPĚCH, Pavel. 2014. "Discursive No Man's Land: Analysing the Discourse of the Rural in the Transitional Czech Republic.” Journal of Rural Studies 34: 96-107.

PRED, Allan. 1984. "Place as Historically Contingent Process: Structuration and the Time-Geography of Becoming Places." Annals of the Association of American Geographers 74(2): 279-297.

SCHWAB-TRAPP, Michael. 2006. "Diskurs als soziologisches Konzept: Bausteine einer soziologisch orientierten Diskursanalyse.” Pp. 263-285 in Handbuch Sozialwissenschaftlicher Diskursanalyse. Band I: Theorien und Methoden, edited by Reiner KELLER, Andreas HIRSELAND, Werner SCHNEIDER and Willy VIEHÖVER. Wiesbaden: VS Verlag für Sozialwissenschaften.

SHEARMUR, Richard. 2012. "Are Cities the Fond of Innovation? A Critical Review of the Literature on Cities and Innovation." Cities 29(2): S9-S18.

SHUCKSMITH, Mark, Stuart CAMERON, Tanya MERRIDEW and Florian PICHLER. 2009. "Urban-Rural Differences in Quality of Life Across the European Union." Regional Studies 43(10): $1275-1289$.

SMITH, Adrian and Judit TIMÁR. 2010. "Uneven Transformations: Space, Economy and Society 20 years After the Collapse of State Socialism.” European Urban and Regional Studies 17(2): $115-125$.

SOOVÄLI, Helen. 2004. Saaremaa Waltz: Landscape Imagery of Saaremaa Island in the 20th Century. Tartu: University of Tartu Press.

SPIVAK, Gayatri Chakravorty. 1988. Can the Subaltern Speak? Postkolonialität und subalterne Artikulation. Wien: Turia and Kant.

STATISTICS ESTONIA. 2009. "According to the Regional Development, Estonia Can Be Divided into Three Parts.” News Release No. 139. Retrieved February 15, 2016 (http://www.stat.ee/38531).

STATISTICS ESTONIA. 2015. "Social Exclusion and Poverty." Statistical Yearbook of Estonia. Retrieved February 15, 2016 (http://www.stat.ee/social-exclusion-and-poverty).

STEINFÜHRER, Annett. 2015. "'Landflucht' und 'sterbende Städte': Diskurse über ländliche Schrumpfung in Vergangenheit und Gegenwart.” Geographische Rundschau 9: 4-10.

STENNING, Alison and Kathrin HÖRSCHELMANN. 2008. "Ethnographies of Postsocialist Change." Progress in Human Geography 32(3): 339-361. 
SUCHLAND, Jennifer. 2011. “Is Postsocialism Transnational?” Signs 36(4): 837-862.

TIMÁR, Judit and Gábor VELKEY. 2016. "The Relevance of the Political Economic Approach: The Interpretation of the Rural in the Migration Decision of Young Women and Men in an Economically Backward Region.” Journal of Rural Studies 43: 311-322.

TLOSTANOVA, Madina. 2012. "Can the Post-Soviet Think? On Coloniality of Knowledge, External Imperial and Double Colonial Difference." Intersections: East European Journal of Society and Politics 1(2): 38-58.

TRELL, Elen-Maarja, Bettina VAN HOVEN and Paulus HUIGEN. 2012. "It's Good to Live in Järva-Jaani but We Can't Stay Here: Youth and Belonging in Rural Estonia." Journal of Rural Studies 28(2): 139-148.

VIRKKUNEN, Joni. 2002. "Place and Discourse in the Formation of the Northeast Estonian Borderland." Pp. 239-254 in Boundaries and Place: European Borderlands in Geographical Context, edited by David H. KAPLAN and Jouni HÄKLI. Lanham: Rowman and Littlefield Publishers.

WACQUANT, Loïc, Tom SLATER and Virgilio B. PEREIRA. 2014. "Territorial Stigmatization in Action." Environment and Planning A 46(6): 1270-1280.

WOODS, Michael. 2010. "Performing Rurality and Practicing Rural Geography." Progress in Human Geography 34(6): 835-846.

\section{Author}

Bianka Plüschke-Altof is $\mathrm{PhD}$ candidate at the University of Tartu and Early Stage Researcher at Geomedia OÜ in the framework of the Marie Curie International Training Network $\mathrm{RegPol}^{2}$.

Contact: pluschke@ut.ee 